\title{
The Influence of Transformational Leadership on Employees Performance with Communication Satisfaction Mediation (Case Study of Frontliner Employees of PT Bank Muamalat, TBK Surabaya)
}

\author{
N.K. Wardani *, A. Eliyana \\ Universitas Airlangga \\ Surabaya, Indonesia
}

\begin{abstract}
This research purpose is to find out the influence of transformational leadership to employee's performance with mediation communication satisfaction on front liner employees of PT Bank Muamalat Indonesia, Tbk at Surabaya.The respondent for this research is determined as $\mathbf{2 7}$ front liner employees at office area Surabaya PT Bank Muamalat Indonesia, Tbk. Technique of sample collection used in this research was a total sampling of $\mathbf{3 7}$ respondents and used path analysis with the support of SPSS 12 program. Research result showed that the transformational leadership as a positive and significant influence to employee's performance, the transformational leadership has a positive and significant influence to communication satisfaction, communication satisfaction as a positive and significant influence to employee's performance, communication satisfaction partially mediation relationship between transformational leadership with employee's performance.
\end{abstract}

Keywords-Transformational Leadership; Employee Performance; Communication

\section{INTRODUCTION}

The birth of Islamic banks in Indonesia is driven by the desire of the people of Indonesia (especially the Islamic community) who views that interest is usury, so it is prohibited by religion. The legal aspect underlying the development of sharia banks in Indonesia is Law No. 7 of 1992. In the law of shariah principle is still vague, which is stated as the principle of profit sharing. The principles of sharia banking are explicitly stated in Law No. 10 of 1998, which is then amended by Act Number 23 of 1999 concerning Bank Indonesia and Law No. 3 of 2004, the development of financial institutions that use sharia principles began in 1992 preceded by the establishment of Bank Muamalat Indonesia (BMI) as the first sharia-compliant bank in Indonesia.

Bank Muamalat was established on November 1, 1991 initiated by Majelis Ulama Indonesia (MUI) and the Indonesian government subsequently started operations on 01 May 1992. Behind the current developments, Bank Muamalat Indonesia has a strong mission vision to bring success for the BMI with vision become the premier sharia bank in Indonesia, dominant in the spiritual market, admired in rational markets and with the mission of becoming a role model of the world's sharia financial institutions with an emphasis on entrepreneurial spirit, management excellence and innovative investment orientation to maximize value for stakeholders. The vision of the mission is the hope of Bank Muamalat
Indonesia to the internal public performance of companies that are able to encourage and motivate employees and can lead to good communication and relationships between subordinates and superiors to create satisfaction in communication with respect to comfort.

[1] explains that companies need employees who are able to work better and faster, so that required employees who have high performance (job performance). An important factor determining employee performance and organizational ability to adapt to environmental change according to [1] is leadership. Leadership describes the relationship between the leader (leader) and the led (follower) and how a leader directs the follower will determine how far the follower reaches the leader's goals or expectations [1].

Referring to research [2] states that communication satisfaction is associated with high levels of performance in work and job satisfaction and communication become the core process for the success or failure of an organization. Furthermore, [3] say that through an employee communication learning what is expected of them, understanding how they are doing the job and realizing what others think about their work. The quotation can be said that the communication that occurs in the organization both from leaders and with colleagues determines how an employee does his job with a significant outcome. When a leader can apply a transformational leadership style through good communication skills with employees both individually and related to the work will cause the satisfaction of communicating in the minds of employees to grow comfort and respect by the employees themselves in carrying out its performance that will affect the fulfillment of corporate targets.

The object of this research is frontliner employee of PT. Bank Muamalat Indonesia, Tbk section teller and customer service which then will be given a questionnaire to assess the transformational leadership applied by the leader or direct superior of frontliner employees in each branch in Surabaya that can affect their performance through the communication satisfaction perceived by employees is based on the statement of the questionnaire given. Therefore, based on this description, the research was prepared under the title: The Influence of Transformational Leadership on Employee Performance with Communication Satisfaction Mediation (Case Study of Frontliner Employees of PT Bank Muamalat Indonesia, Tbk Surabaya). 
analyzes by [10] have asserted a positive relationship between transformational leadership and performance reported in the literature.

[11] suggests that there is a positively positive relationship between two transformational factors (providing individual support and accepting group goals) and determining the individual in a performance role.

From the above mentioned variations of variables relationships it can be concluded that transformational leadership in the banking world can have a positive impact on long-term employee performance, this is because transformational leadership behaviors can inspire subordinates to work better and committed and can create a cohesive culture in an atmosphere their work.

2. The Relationship between Transformational Leadership, Communication Satisfaction, and Employees Performance

[12] in a study entitled "The Impact of Leadership on The Communication Satisfaction of Primary School Teachers in Serbia" shows the result that transformational leadership has a strong and significant positive relationship to the communication satisfaction of elementary school teachers in Serbia. It shows that when leaders communicate their vision effectively, leaders will gain trust from their followers, which then contribute to communication satisfaction between leader and follower [12].

[4] suggests that effective leaders tend to use two different forms of communication (ie task and relational) when interacting with subordinates. There have been previous studies that show that leadership establishes communication and divides it into messages (tasks) and describes (the connecting dimensions) of the message [4].

According to [12] there is a positive and significant relationship between the supervisory leadership style and the performance and employee communication satisfaction.

H1. Transformational leadership significantly positively affects the performance of frontliner employees at PT. Bank Muamalat Indonesia, Tbk

H2. Transformational leadership significantly positively affects communication satisfaction at PT. Bank Muamalat Indonesia, Tbk

H3. Communication satisfaction significantly positively affect the performance of frontliner employees of PT. Bank Muamalat Indonesia, Tbk

H4. Communication satisfaction significantly positively mediates transformational leadership on the performance of frontliner employees at PT. Bank Muamalat Indonesia, Tbk.

\section{METHODOLOGY}

In accordance with the purpose of research is to determine the effect of transformational leadership on employee hypothesis of relationships between transformational
leadership, transactional leadership and performance. Meta-

[9] and [10] accumulate literature that tests transformational leadership theories have provided results that support the

\section{Leadership is defined in many ways, such as the ability to through certain symbols that mean to the recipient of the message. [8] states that communication is a behavior, deeds or} 2.4 Definition of Employees Perfomance representing the level of achievement of eac fillment of policies, expectations or requirements for performance in the organization will also be high [8]. The next after the completion of a mission by individuals or groups [8].

\subsection{RELATIONSHIP BETWEEN VARIABLE}

1. The Relationship between Transformational Leadership and Employees Performance 
achievement of targets variable in PT. Bank Muamalat Indonesia, Tbk which refers to the formulation of problems and hypotheses that have been established, then this research uses a quantitative approach, namely research that uses the process of rationalization of a phenomenon that occurs and measures the variables that have been determined to make generalizable conclusions.

In this research, independent variable symbol $(\mathrm{X})$ is transformational leadership, symbolized variable $(Z)$ is employee performance, and intervening variable in this research is symbol $(\mathrm{Y})$ that is communication satisfaction.

The response of each indicator is measured by using a Likert scale scoring, meaning that every answer of all these measurement indicators represents the score or weight on the alternative answers given by the respondent. The use of these five Likert scales to avoid biased responses and reduce the respondents' doubts in choosing answers to each of the statements presented.

The type of data used in this study are primary data and secondary data. The procedure in collecting data in this research is done through a systematic procedure, that is through survey technique, questionnaire distribution and literature study.

In this study the respondents used are frontliner employees of PT. Bank Muamalat Indonesia Tbk part teller and customer service at branch offices under Surabaya Darmo area and Surabaya KH area. Mas Mansyur which has a population of 37 employees. This study uses regression approach by using path analysis to analyze all variables under study according to the theory used. Path analysis technique using SPSS 13 program. Data analysis methods include: Descriptive Statistics, Path Analysis, Hypothesis Testing, Mediation Testing, Test Validity and Reliability.

$$
\text { IV. RESUlt And Discussion }
$$

Table 1. Validity Test Results of Transformational Leadership Variables

$\begin{array}{ll}\text { Indicators } & \begin{array}{l}\text { Pearson } \\ \text { Correlation }\end{array}\end{array}$ Criteria Remarks

\begin{tabular}{|c|c|c|c|}
\hline $\begin{array}{l}\text { My leadership is always } \\
\text { concerned with the needs } \\
\text { of career development of } \\
\text { his subordinates }\end{array}$ & 0,874 & 0,30 & Valid \\
\hline $\begin{array}{l}\text { My leadership is always } \\
\text { questioning the } \\
\text { assumptions used to make } \\
\text { decisions }\end{array}$ & 0,861 & 0,30 & Valid \\
\hline $\begin{array}{l}\text { My leadership always } \\
\text { delivers an exciting future } \\
\text { vision of branch } \\
\text { achievement }\end{array}$ & 0,818 & 0,30 & Valid \\
\hline $\begin{array}{l}\text { My leadership can always } \\
\text { be a role model for his } \\
\text { subordinates in } \\
\text { encouraging the }\end{array}$ & 0,890 & 0,30 & Valid \\
\hline
\end{tabular}

\section{Source: Appendix 4}

Based on Table 1 it is known that all the question indicator on Transformational Leadership variables have coefficient value $r>0.30$, thus the four indicator questions that measure the transformational leadership variable are declared valid.

Table 2. Validity Test Results Employee Performance Variables

\begin{tabular}{lll}
\hline Indicators & $\begin{array}{l}\text { Pearson } \\
\text { Correlation }\end{array}$ & Criteria Remarks
\end{tabular}

Whether this employee can reach the target in conducting cross selling products to customers? Does this employee have quality work which is good in providing services to customers?

Does this employee have knowledge

about the products owned by

PT Bank Muamalat Valid

Indonesia, Tbk?

Does this employee have creativity in giving an opinion or an idea when completing his work?

$$
\text { Source: Appendix } 4
$$

Based on Table 2, it is known that all question items on employee performance variables have coefficient $r$ value> 0.30 , thus the eight indicator questions that measure employee performance variables are stated to be valid.

Table 3. Reliability Test Results Variable Research

\begin{tabular}{llcc}
\multicolumn{1}{c}{ Variables } & $\begin{array}{c}\text { Cronbach } \\
\text { Alpha }\end{array}$ & Criteria & Remarks \\
\hline $\begin{array}{l}\text { Transformational } \\
\text { Leadership (X) }\end{array}$ & 0,883 & 0,60 & Reliable \\
$\begin{array}{l}\text { Employees } \\
\text { Performance((Y) } \\
\text { Communication }\end{array}$ & 0,845 & 0,60 & Reliable \\
Satisfaction (Z) & 0,797 & 0,60 & Reliable \\
\hline \multicolumn{1}{c}{ Source: Appendix 4} & &
\end{tabular}


VIF $<10$, thus it is concluded that the equation model 2 is free of multicollinearity.

Table5. Test Result Normality Kolmogorov-Smirnov indicator that measures the research variables is considered reliable.

Table 4.Multicollinearity Test Results

\begin{tabular}{|c|c|c|c|}
\hline \multirow{2}{*}{ Model } & \multirow{2}{*}{ Variables } & \multicolumn{2}{|c|}{ Collinearity Statistics } \\
\hline & & Tolerance & VIF \\
\hline \multirow[t]{2}{*}{2} & $\begin{array}{l}\text { Transformational } \\
\text { Leadership (X) }\end{array}$ & 0,501 & 1,997 \\
\hline & $\begin{array}{l}\text { Communication } \\
\text { Satisfaction }(Z)\end{array}$ & 0,501 & 1,997 \\
\hline
\end{tabular}

\section{Source: Appendix 5}

Based on Table 4.14 it is known that the independent variables in model equation 2 have a tolerance value $>0.1$ and Table 6. Path Coefficient Value

\begin{tabular}{llllll}
\hline Variables & & & $\begin{array}{l}\text { Path } \\
\text { Coefficient }\end{array}$ & t-count & Sig \\
\hline Transformational Leadership & $\rightarrow$ & $\begin{array}{l}\text { Employees } \\
\text { Performance }\end{array}$ & 0,322 & 2,138 & 0,040 \\
Communication Satisfaction & $\rightarrow$ & $\begin{array}{l}\text { Employees } \\
\text { Performance } \\
\text { R-Square }=0,614\end{array}$ & 3,464 & 0,001 \\
Transformational Leadership & $\rightarrow \begin{array}{l}\text { Communication } \\
\text { Satisfaction }\end{array}$ & 0,707 & 5,907 & 0,000
\end{tabular}

Source: Appendix 6

R-Square $=0,499$

From Table 6 it is known that the path variable coefficient of transformational leadership attitude toward employee performance is 0,322 , with significance value equal to 0,040 $<0,05(\alpha=5 \%)$. These results indicate that transformational leadership has a positive and significant effect on employee performance on PT. Bank Muamalat Indonesia, Tbk. That is, if there is a change in transformational leadership variable then there will be changes also on the performance of employees significantly.

Path coefficient of communication satisfaction variable to employee performance is 0,522 , with significance value equal to $0,001<0,05(\alpha=5 \%)$. These results indicate that communication satisfaction also has a positive and significant effect on employee performance on PT. Bank Muamalat Indonesia, Tbk. That is, if there is a change in the variable of communication satisfaction then there will be changes also on the performance of employees significantly.

The resulting $\mathrm{R}$-Square value of 0.614 indicates that the diversity of communication satisfaction in the employees of
PT. Bank Muamalat Indonesia, Tbk can be explained by transformational leadership and communication satisfaction of $61.4 \%$, while the remaining $39.6 \%$ is explained by factors other than transformational leadership and communication satisfaction.

Furthermore, it is known that transformational leadership path coefficient on communication satisfaction is 0.707 with a significance value of $0.000<0.05(\alpha=5 \%)$. These results indicate that transformational leadership has a positive and significant impact on communication satisfaction on employees of PT. Bank Muamalat Indonesia, Tbk. That is, if there is a change in transformational leadership variable then there will be also changes in communication satisfaction significantly.

The value of R-Square generated regression of 0.499 indicates that the diversity of communication satisfaction in employees of PT. Bank Muamalat Indonesia, Tbk can be explained by a transformational leadership attitude of $49.9 \%$, while the remaining $50.1 \%$ is explained by other factors. 
Table7.Hypothesis Test Results

\begin{tabular}{llllll}
\hline Variables & & & Path Coefficient & t-count & Sig \\
\hline Transformational Leadership & $\rightarrow$ & $\begin{array}{l}\text { Communication } \\
\text { Satisfaction }\end{array}$ & 5,907 & 0,000 & Significant \\
$\begin{array}{l}\text { Transformational } \\
\begin{array}{l}\text { Leadership } \\
\text { Communication Satisfaction }\end{array}\end{array}$ & $\rightarrow$ & Employees Performance & 2,138 & 0,040 & Significant \\
& & Employees Performance & 3,464 & 0,001 & Significant
\end{tabular}

Source:

Based on table 4:17 the results of hypothesis testing can be explained as follows:

Variable of transformational leadership to employee performance obtained by t-count 2,138 with significance level equal to $0,040<0,05(\alpha=5 \%)$. Based on this result, the first hypothesis of research that suspect that transformational leadership significantly positively affect the performance of frontliner scientists at PT. Bank Muamalat Indonesia Tbk, is acceptable.

This shows that the higher the intensity of the application of transformational leadership by the frontliner's direct employer, the higher the performance of frontliner employees of PT Bank Muamalat Indonesia, Tbk. Vice versa, the lower the intensity of the application of transformational leadership by the frontliner's direct employer, the lower the performance level of frontliner employees of PT Bank Muamalat Indonesia Tbk.

Variable of transformational leadership toward communication satisfaction obtained by t-count value of 5,907 with significance level equal to $0,040<0,05(\alpha=5 \%)$. Based on this result, the second hypothesis of research that suspect that transformational leadership significantly positively affect the communication satisfaction at PT. Bank Muamalat Indonesia Tbk, is acceptable.

This indicates that the higher the intensity of the application of transformational leadership by the frontliner's direct employer's employer, the higher the level of employee communication satisfaction with the leadership of PT Bank Muamalat Indonesia, Tbk. Vice versa, the lower the intensity of the application of transformational leadership by the frontliner employee's immediate employee, the lower the level of employee communication satisfaction with the leadership of PT Bank Muamalat Indonesia, Tbk.

Variable of communication satisfaction on employee performance obtained by tcount equal to 3,464 with significance level equal to $0,001<0,05(\alpha=5 \%)$. Based on these results, the third hypothesis of research that suspects that communication satisfaction significantly positively affect the
Appendix 6 performance of frontliner employees of PT. Bank Muamalat Indonesia Tbk, is acceptable.

This shows that the higher level of communication satisfaction with the frontliner employees, the higher the level of performance of frontliner employees of PT Bank Muamalat Indonesia, Tbk. Vice versa, the lower the satisfaction of leadership communication with frontliner employees, the lower the level of performance of frontliner employees of PT Bank Muamalat Indonesia, Tbk.

Hypothesis testing of transformational leadership variables on employee performance through communication satisfaction as intervening variables obtained by multiplying the path coefficient on the path $\mathrm{X} \square \mathrm{Z}$ and $\mathrm{Z} \square \mathrm{Y}$ is $0.707 \times 0.522=$ 0.369 . The amount of indirect influence is still greater than the direct influence of 0.322 which means that the variable of communication satisfaction can be an intervening variable. Thus the fourth hypothesis which suspects that communication satisfaction significantly positively mediates transformational leadership on the performance of frontliner employees at PT. Bank Muamalat Indonesia Tbk, is acceptable.

Based on the testing of mediation variables, it is evident that communication variables mediate transformational leadership relationships and partial employee performance. The results of the tests show that the factor of employee performance improvement is not only due to the communication satisfaction of the leader with his subordinates, but also influenced by the leader's role in carrying out leadership through the application of transformational leadership. Transformational leadership and communication satisfaction alike have a role in improving the performance of frontliner employees of PT Bank Muamalat Indonesia, Tbk. The findings of this study are supported by Pearce and Segal (1998) in Alsayed et al., (2012) which says that communication satisfaction indirectly affects employee performance.

\section{CONCLUSION}

From the results of research and statistical tests on the influence of transformational leadership on employee 
[3] Orpen, C. (1997). The inteactive effects of communication quality and job involvement on managerial job satisfaction and work motivation. The Journal of Psychology. 131(5), p519-522

concluded as follows:

a. The first hypothesis to suppose that transformational leadership significantly positively affects the performance of frontliner employees at PT Bank Muamalat Indonesia Tbk is acceptable.

b. The second hypothesis that alleged that transformational leadership significantly positively affects communication satisfaction at PT Bank Muamalat Indonesia, Tbk is acceptable.

c. The third hypothesis that alleged that communication satisfaction significantly positively affects the performance of frontliner employees at PT Bank Muamalat Indonesia, Tbk is acceptable.

d. A fourth hypothesis that allegedly positive communication satisfaction mediates transformational leadership on the performance of frontliner employees at PT Bank Muamalat Indonesia Tbk is acceptable.

\section{REFERENCES}

[1] Maulizar, Said Musnadi, Mukhlis Yunus. (2012). Pengaruh Kepemimpinan transaksional dan Transformasional Terhadap Kinerja Karyawan Bank Syariah Mandiri Cabang Banda. Jurnal Manajemen Pascasarjana Universitas Syiah Kuala. P58-65

[2] Goris, J. R. (2007). Effects of Satisfaction With Communication on The Relationship Between Individual-Job Congruence and Job Performance/Satisfaction. Journal of Management Development. Vol. 26 No.8, p737-752
4] Madlock, P.F. (2012). The influences of supervisors' leadeship style on telecommuters. Journal of business strategies. Vol. 29, p1-24

[5] Lussier, Robert N. and F. Achua, Christopher, (2010) Leadership Theory, Application, and Skill Development, 4th Edition (Mason, Ohio : South-Western Cengage Learning.

[6] McMurray, A.J, Islam, M.M, Sarros, J.C dan Pirola-Merlo, A. (2012). The Impact of Leadership on Workgroup Climate and Peformance in a Non-profit Organization. Leadership and Organization Development Journal. Vol. 33 No. 6, p522-549

[7] AW, Suranto, 2005, Komunikasi Perkantoran; Prinsip Komunikasi untuk Meningkatkan Kinerja Perkantoran, Cetakan I. Depok, Yogyakarta:Media Wacana.

[8] Yeh, Hueryren dan Dachuan Hong. 2012. The Mediating Effect of Organizational Commitment on Leadership Type and Job Performance.The Journal of Human Resource and Adult Learning, V 50 ol. 8, Num. 2, December 201

[9] Avolio, B.J., Waldman, D.A., Yammarino, F,J. (1991). Leading in The 1990s: The Four I's of Transformational Leadership. Journal of

[10] Bass, B.M., Jung, D.I., Avolio, B.J., Berson, Y. (2003). Predicting Unit Performance by Assessing Transformational Leadership and Transactional Leadership. Journal of Psychology, Vol 88 No. 2, p207218

[11] Rank, Nelson, Allen and Xu. (2008). Leadership predictors of innovation and task performance: Subordinates' self-esteem and selfpresentation as moderators. Journal of Occupational Psychology

[12] Terek, E, Milan Nikolic, Bojana Gligorovic, Dragana Glusac, Ivan Tasic. (2014). European Industrial Training. Vol 15 No 4, p9-16 